\title{
ETHNICITY, INEQUALITY AND THE TRAGEDY OF AFRICAN DEVELOPMENT: A COMPARATIVE CASE STUDY OF NIGERIA AND THE SOUTH SUDAN
}

\author{
Ajibade Samuel Idowu, Abiodun Akeem Oladiti, \\ and Adetoun Esther Adenuga
}

\begin{abstract}
This paper provides theoretical insights on the behaviour of ethnicity in the developmental experience of two African countries, namely, Nigeria and South Sudan, which have been regarded as failed states not due to their heterogenic configurations but due to the adverse effects of ethnicity and inequality. This paper reinforces the argument that political and social instability are the major causes of African underdevelopment. It posits that ethnicity encapsulates these factors using the cases of Nigeria and South Sudan to offer germane examples of the hydra-headed effects of ethnicity. Since independence, the surge of inequality in Africa has been driven not by the revolution in technology but by ethnicity and its concomitants. Africa is also the continent with the highest rate of poverty, illiteracy, and infant mortality. As palliatives, several development and international financial aid programmes have tried to address the issues of poverty and underdevelopment in Africa, Asia and Latin America. While these programs yielded results in some parts of the world, they were almost a failure in Africa. Indeed, ethnicity remains a source of conflict used by nationalist and political entrepreneurs to promote their ambitions at the expense of Africa's development. This paper established the relationship between ethnicity and development and its dimension on inequalities. It argued that ethnicity and inequality are complex social constructs, that have continually retarded Africa's development.
\end{abstract}

Keywords: ethnicity, development, inequalities, Nigeria, South Sudan.

\section{Introduction}

Most African countries are regarded as failed states. The failed states, which are conspicuously underdeveloped, are those states that are unable to provide their citizens with necessities such as health care, security, employment and good infrastructures (Ekokobe Awung 2011: 2). According to the United Nations Development Programme (UNDP), Africa ranked low in the global human development index with Nigeria ranking 152, South Sudan - 169 and Niger - 188 out of 188 countries (Human Development Report 2015: 210-211). This gives a clear indication that the majority of African countries are failed states. Warburton (2005: 1) concludes that the factors that encumber Africa's development include oppressive regime, corruption and international complicity. In the same vein, Asafa (2015: 79) contends that the causes of Africa's underdevelopment are tripartite namely: colonial capitalism, state terrorism and racism.

In the same vein, Easterly and Levine (1997: 1203) point to a diverse set of potential causes of Africa's development dilemma, ranging from bad policies, to poor educa-

Journal of Globalization Studies, Vol. 10 No. 1, May 2019 111-129

DOI: $10.30884 / j o g s / 2019.01 .08$ 
tion, political instability and inadequate infrastructure. However, of all the reasons enumerated above as the problems of African development, ethnicity and inequality are considered as the most volatile by this paper. Thus, this paper contends that the duo have more than any factor contributed to the continent's underdevelopment.

Ethnicity and inequality are combined forces that sap the time and energies of Africans. Rather than just concentrating on technological and economic development, African countries focus on contending with the devastating effects of the application and misapplication of ethnicity and inequality. Scholars have looked at ethnicity mainly from the conflict point of view. There is no doubt that ethnicity is the major factor that often leads to conflict in Africa. Put differently, it is instructive to note that in the areas of power sharing, employment, healthcare, education and access to other basic necessities of life, ethnicity stands out as a major agent of who gets what. This paper thus attempts to bring to the fore how ethnicity has led to the unequal distribution of the general good in Africa leading to the underdevelopment of the continent.

Most African countries employed ethnicity to attain independence but allowed the same to tear them apart after independence. While Nigeria experienced a three-year long civil war between 1967 and 1970, the civil war in South Sudan in 2011 is relatively recent when compared to that of Nigeria. However, both civil wars have their origins in ethnicity and still determine the socio-economic and political progress of these countries. The paper also examines the level of ethnicity and inequality in these countries with the aim of reinforcing the argument that political and social instability are the major causes of African underdevelopment, and positing that ethnicity and inequality encapsulate these factors. Thus, this paper concludes that more than any other factor, ethnicity intertwines with inequality to retard African development.

\section{Ethnicity in Africa: A Discourse}

Ethnicity in Africa is hydra and pugnacious. It is explained in terms of ethnic violence, ethnic politics, ethno-religious conflicts, etc. Ethnic conflict or violence has spawned several genocidal conflicts in Africa with disastrous consequences on the overall development of the continent. Virtually every African conflict has some ethno-regional dimension in it. Even those conflicts that may appear to be free of ethnic concerns involve factions and alliances built around ethnic loyalties (Deng 1997). Ethnicity continues to pose a security threat to many African countries and has had adverse effects on prospects of promoting good governance or democracy. African countries since colonialism have continued to use ethnicity as a resource for political manipulation and entrepreneurship, resulting in dominant ethnic groups excluding minority groups within national policies that reflect the interests and activities of the national majority (Butale 2015).

Indeed, ethnicity or issues related to it are essentially the major cause of underdevelopment in Africa; the political instability, chaos, bloodshed and severe structural damage accompanying it are potential features of a weak state. Unfortunately, however, in most instances, many politicians across Africa continue to use ethnicity to promote themselves and inflict maximum political damage on their opponents. The advent of multiparty politics at the twilight of African independence was characterised by the emergence of ethnic-based political parties. The main objective is to protect kith and kin at the expense of inclusive democracy and political pluralism. Unfortunately, how- 
ever, in today's Africa, ethnic politics has contributed to the suppression of social harmony, diversity and development enjoyed before the advent of colonialism.

According to Yang (2000: 29) ethnicity, is defined as an affiliation or identification with an ethnic group. It is the outcome of subjective perception based on some objective characteristics such as physical attributes, presumed ancestry, culture or national origin. Conversely, however, the criteria for defining an ethnic group in Africa normally include language, territory, common history, cultural values or symbols and an active sense of self-determination.

Nnoli (1998) sees ethnicity as a social phenomenon associated with the identity of members of the largest possible competing communal groups (ethnic groups) seeking to protect and advance their interests in a political system. On the other hand, he views ethnicity as a divisive phenomenon since the members of a particular ethnic group strongly identify themselves with the group in terms of feelings and sentiments against other ethnic groups. The dominant ethnic group usually has a feeling that no other ethnic group should take the lead in every sphere within the polity (Nnoli 1980: 5).

Both Marxist and modernist theorists have predicted that as a society becomes industrialised and modernised, ethnicity will fade and eventually die out. On the contrary, not only has ethnicity remained a vital and important part of contemporary life, but its significance has been on the ascendance at certain times and in certain places. Ethnicity affects the opportunities of members of different ethnic groups in schools, jobs, income, housing poverty, crime and politics (Yang 2000: 41).

Umezinwa (2012) perceives ethnicity as a gift from nature, which is therefore good in itself. Like every other natural phenomenon, it can be gainfully employed for the wellbeing of man. It is a fruitless and an impossible effort trying to get rid of it completely in the society (Umezinwa 2012:229). This explains the positive role of ethnicity during the struggle for independence in Africa. However, after the demise of colonialism, it took a new twist to become an agent of destabilisation and disintegration. Ethnicity is a strong factor in the socio-political and economic life of several African states.

The fact that Africa operates on artificially drawn boundaries as a result of colonialism arguably may not be a problem per se. One of the myriad of problems of independent African states was the desire to dominate or the fear of being dominated by other ethnic groups located within these boundaries. This often leads to outright declaration of hostilities resulting inexorably in loss of lives and property. Nigeria was engulfed in the 30 months civil war as a result of ethnic tension that had brewed for a long period of time. The war was fought, won and lost but the ethnic suspicions and hatred still remain unabated. The Rwandan genocide and the Sudanese almost intractable wars were also motivated by ethnicity. There is no country in all the sub-regions of Africa that is immune from ethnicity and its pugnacity. Thus, other countries that have experienced ethnic or sub-ethnic conflicts are Somalia, Liberia, Zimbabwe, Angola, Burundi, Congo DRC, Ethiopia and Uganda. Ethnic factor is still having its toll in these countries.

Since independence, political actors (in Africa) activate ethnicity strategically for group organisation, interest definition, and collective action to advance political goals. Thus, ethnicity serves as an important source of strategic coordination over votes and seats (Mozaffar 2006: 239); African countries are known to vote on ethnic lines. In Kenya, for example, ethnicity has emerged as the main factor explaining electoral 
behaviour in the country. There is no denying the fact that ethnic affiliation and loyalty play a significant role in determining electoral choice, but ethnicity can also be seen as an epiphenomenon, going hand in hand with inequality and discrimination. However, there are objective foundations of ethnic thinking that are often not brought to the fore (Archer 2009). In Nigeria, all the parties formed at the exit of colonialism were ethnicbased, thus, making ethnic affiliation a major determinant of election. These political parties relied on ethnicity for mobilising electoral support.

Ethnicity in sub-Saharan Africa has continually polarised the various polities. Several associations and militias are formed along ethnic lines and even in some cases, political parties are often ethnic-based. In Nigeria, for example, there are the Arewa consultative forum, Afenifere, Ohaneze Ndi Igbo Movement for the Actualisation of the Sovereign State of Biafra (MASSOB), etc. Among the governors, we have South East governors' forum, Northern governors' forum, etc. Each is formed with an aim of gaining political advantage over the rest. All these are indications pointing to the destructive impact of ethnicity in Nigeria. With all these groups around it will be very difficult to organize a popular uprising against the government as witnessed in Tunisia, Egypt, Libya, Syria, etc. (Umezinwa 2012: 225). More than any other factor, ethnicity has become a major cause of conflict on the continent (see, e.g., Osaghae 1992).

Africa has witnessed more conflicts than any other continent in the world. Since the Congo crisis of the 1960s, the UN Security Council has exerted more time and resources resolving conflicts and performing humanitarian duties in Africa than any other part of the world. Ethnicity has also bred the feelings of suspicion, hatred and distrust among members of various ethnic groups in Africa and has no doubt retarded political integration in Africa. It is therefore not surprising to note that at least twice (1967-1970 civil war and 1993-1999 friction) ethnic rivalry has been the major cause of internal conflicts in Nigeria. Similar stories may also be told of Liberia, Uganda, Rwanda, Burundi, Somalia, Sudan, Congo and a host of other Africa states (Olaosebikan 2010: 552).

The multiplicity of ethnic groups does not by itself lead to violence and conflict (Rupesinghe and Tishkov 1996: 298). What is significant is that the dichotomy existing between the minority and majority ethnic groups often becomes highly competitive in which the minority becomes aggrieved over unequal distribution of political and economic goods of the state. Thus, the agitation of the minority against the majority is a dominant feature of ethnicity in Africa. Kenya has about 42 ethnic groups with the Kikyuyu, Luo and Kalenjin as the dominant or majority ethnic groups. Uganda is home to more than 40 different indigenous ethnic groups, including the Baganda, Iteso, Basoga and Banyankore - all of which have their own languages, cultures and customs (Blake 2013). According to CIA data, the Baganda are the largest ethnic group in the country, accounting for around one in every six Ugandans. The population of Uganda is approximately 37.8 million and made up of various ethnic groups. The largest ethnic group in Uganda is the Baganda. These people make up 16.9 per cent of the population followed by the Baganda and Bayankole respectively (Largest Ethnic Groups in Uganda 2018).

South Sudan with a population of about 10 million has 64 different ethnic groups (South Sudan Country Profile). The Dinka ethnic group takes about 36 per cent of the population while the Nuer ethnic group comprises about 16 per cent of the population. 
The Bari ethnic group is the fourth largest in South Sudan after the Dinka, the Nuer and the Azande (Tongun Lo Loyuong 2014).

The Democratic Republic of the Congo is more ethnically diverse with more than 200 different ethnic groups. As estimated, alongside French, which is the official language, 215 native languages are spoken in the country (Ethnic Groups 2018). It is divided into three major ethnic groups namely Bakongo, which make up almost half of the entire population, Bateke about 20 per cent and M'Boshi 15 per cent (Skutsch 2006: 589).

The importance of the above is to further elucidate the pugnacity of ethnic diversity in Africa. It also demonstrates that it has always bred the majority versus the minority dichotomy with severe consequences on African development. These African nations are located within their various states made up of people belonging to different ethnic backgrounds and which have ended up living within the same country partly as a product of immigration and mostly as a product of colonialism. Generally, ethnicity becomes intense with the agitations of minority ethnic groups against the majority ethnic groups. In Africa, problems of ethnic majority domination and ethnic minority agitation have always slowed down Africa's development. In Nigeria, for example, whereas the three major ethnic groups keep dominating the sphere, the minority groups among the youth of the Niger-delta directed their grievance against the government and the foreign oil companies in the community always agitate often violently due to frustration occasioned by environmental degradation, underdevelopment and the lack of all forms of social amenities and infrastructures (Dickson and Dadiowei 2010: 465-486). These countries represent states in Africa where ethnic minorities continue to face major disadvantages in their access to political and economic resources.

Paglia (2007) argues that ethnicity cannot be the root cause of African conflicts based on the following arguments: the historical period and events (such as colonialism, neocolonialism, the Cold War, and the collapse of the Soviet Union) helped to create and fecundate conflict and even underdevelopment of the continent (Paglia 2007). However, it should be noted that one of such historical periods and events was instrumental to the creation of artificial boundaries, which has in turn created ethnic chauvinism within the continent. Ethnicity has been seen as one of the problems of underdevelopment in Africa. Scholars are divided over the impact of ethnicity on national development. Whereas some contend that ethnicity is a potential factor that contributes to development, others argue that ethnicity is a factor that undermines development. Alesina et al. (2016) for example, posit that ethnicity produces diversity, which has both costs and benefits. On the one hand, such diversity promotes skills, education and endowments which can enhance productivity by promoting innovation, while on the other hand, ethnicity diversity is often associated with poor and ethnically targeted policies, inefficient provision of public goods and ethnic-based hatred and conflict (Alesina et al. 2016: 428). Easterly and Levine argue that political instability, rent-creating economic policies, and poor public goods may reflect a more fundamental country characteristic of ethnic diversity. Ethnicity in Africa has thus spelt tragedy with disastrous consequences (Easterly and Levine 1997: 1205).

Ethnicity has become the basis of political organization relevant to the struggle for democracy in Africa. It plays a crucial role in the struggle to determine who will even- 
tually be included or excluded from access to state resources, power and political representation. Ethnic-group access to state power or the lack of it is an important element of ethnic politics, especially if minority groups are denied access to power and resources based on the small(er) size of their population (even in contexts where they contribute more to national wealth), and that this is likely to lead to increased ethnic consciousness. Thus, access to state power is important for the various ethnic groups because of the extensive intervention of the African state in the political and socioeconomic spheres (Agbu 2011). Consequently, there is always the threat that ethnicity can be used by desperate elites seeking power by any means or that their protesting their exclusion from power can sow seeds of discord in the polity.

\section{Historical Antecedents to the Problem of Ethnicity in Nigeria and South Sudan}

\section{First Case: Nigeria}

The origin of ethnicity in Nigeria began with the British colonial policy that merged the ethnic groups of the northern and southern provinces with over 300 ethnic groups speaking over 150 languages to become an entity called Nigeria in 1914. The segregation of the Nigerian colony was also reinforced by the colonial laws that limited the mobility of Christian Southerners to the Muslim North, which also created a separate settlement for non-indigenous citizens in the North, and even limited the purchase of land outside one's own region. Prejudice and hatred became rife in the provinces as different ethnic groups started looking at each other suspiciously in all spheres of contact. Unequal and differential treatment of ethnic groups was responsible for the intense competition in Nigerian society. It created disparity in educational achievement and widened the political and economic gaps between northern and southern Nigeria (Irobi 2005; Suberu 1996; Osaghae 1991).

The colonial constitutions introduced in Nigeria to a large extent encouraged ethnicity in the country. Of particular importance is the Arthur Richard Constitution of 1946, which introduced federalism and building upon the existing structure of regionalism created by Sir Bourdillon who initiated the idea of regionalism in 1939. He divided the country into provinces and regional councils along the three major ethnics in the country, namely: eastern region, western region and northern region. The creation of the three ethnic regions ignored the needs of the ethnic minority groups for autonomy and self-determination. Instead, they were lost within the majority. This development initiated the belief that one should be loyal to and protect the interest of one's region to the exclusion of the others (Osaghae 1991: 243). However, the Richard constitution established the first regional governments in Nigeria. Although the constitution achieved the integration of North and South in a common legislative council, it actually brought into practice the concept of regionalism (Salawu and Hassan 2011: 30). The implication of this administrative division of the country into three regions reinforced the existence of majority-minority arrangement in which the majority becomes more relevant and dominates each of these regions. Many things have been affected by this tri-polar pattern. The constituted regions were centred on the largest ethnic grouping: the HausaFulani constituted the northern region; the Yoruba formed the western region while the Igbo constituted the eastern region. With the three major ethnic groups in dominance, the minority groups rebelled and Nigerians started fighting for ethnic dominance as the 
nation marched towards independence (Irobi 2005). The 1946 constitution, thus, launched the process of fragmentation along ethnic line in Nigeria. Despite the wide consultation that went into the making of the Macpherson constitution in 1951, the constitution had a major defect. According to the provisions of the constitution, central ministers were to be selected from among the members of regional legislatures. This made the ministers to feel loyal to their regions rather than the centre, which led to inter-regional frictions (Igbuzor 2016).

The constitutional arrangements also encouraged the formation of ethnic-based political parties. For instance, the Action Group (AG) under the leadership of Obafemi Awolowo became the dominant party in the Western Region; the Northern People's Congress (NPC) led by Ahmadu Bello was the dominant political party in the Northern region, while Nnamdi Azikiwe led the National Council of Nigerian Citizens, which was the political giant in the east. These leaders not only played politics of bitterness, they employed ethnicity as a veritable vehicle for selfish political objectives and aggrandizement to the detriment of national integration (Adebisi 1998: 21). For instance, the West African Pilot, a newspaper founded by Nnamdi Azikiwe, which was used for the advancement of NCNC was also used to attack other ethnic groups. Similarly, Obafemi Awolowo, the leader of AG disallowed any party alliance with other political parties of the first republic.

The colonial education policy also helped to sharpen ethnic divide and distrust. While western education was introduced in the southern region (west and south inclusive) in 1843 , the colonialists deliberately disallowed its introduction in the western region until 1903 mainly because of the heavy Islamic influence in that particular region. Allowing education meant allowing the Christian missionaries which may result in conflict and, thus, jeopardising the British economic interest in the north. The effect of this is that the northern region has become irrevocably educationally disadvantaged. The implication of this for ethnicity in Nigeria became evident in the Kano riot of 1953, which broke out as a result of the northern leaders' rejection of early independence for Nigeria due to the fear that the west and east that were educationally advantageous would dominate the polity if the country became independent.

The political crises of 1993, which came as a result of the annulment of the June 12 1993 election, believed to have been won by MKO Abiola, a Yoruba and which was annulled by Ibrahim Babangida, the military president from the north was a continuum of the existing and prevailing ethnic differences in the country in the current political dispensation (Adebayo Oyebade 2002). The agitation of different interest groups such as the Niger Delta avengers, Movement for the Actualisation of the Sovereign State of Biafra (MASSOB) Arewa Consultative Forum (ACF) Odua People's Congress (OPC) etc. is an attestation to the fact that ethnicity remains an important factor of development in the country.

\section{Second Case: South Sudan}

Sudan had separate developments before the Turkish occupation. The North was culturally and religiously tied to the Arab Muslim world; whereas the South was more culturally diversified. The Turkish occupation ended these separate developments. In fact, while penetrating militarily through the South, the Turco-Egyptians brought with them traders 
from Egypt and northern Sudan to exploit the resources of the South. The Turkish occupation is important in two respects. First, it started the exploitation and marginalization of regions, such as the South and Darfur. Second, it created the elite of Muslim Arabs. Colonialism later legitimized these processes and transferred them to postcolonial (Paglia 2007: 30). On January 1, 1956, Sudan gained independence from the AngloEgyptian condominium. Like Nigeria, the decision to merge the predominantly Arab and Muslim north and culturally diverse south into a single administrative region in 1946 created a lasting fundamental problem for the region. Sudan (North and South) was administered separately as a result of acute and irreconcilable geographical, political, cultural distinctions between the two regions of the then Anglo-Egyptian Sudan. The North was ruled in the British colonial policy pattern developed in the Egypt and the Middle East (West Asia). On the other hand, the South was ruled through the indirect rule that was predominate policy in imperial Britain African colonies devised by Lord Lugard in the Northern Emirates of Nigeria in 1898. The separatist policy was so strong that in almost sixty years of the British rule in the then Anglo-Egyptian Sudan, the South Sudanese were never educated at Gordon College (now University of Khartoum). They were educated in British East Africa and Southern Africa. In fact, educational syllabi were equal to those found in British East Africa (de Chand 1995). Some colonial officers were devoted to the South and its peoples, but in general, the British looked more favourably on the north than the south. The colonial administration worked to keep the two sides separate. Christian missionaries were encouraged in southern $\mathrm{Su}$ dan, and forbidden from operating in the north, in order not to antagonise the sentiments of Muslims living there (Copnall 2014: 11). The overriding reason for this was to enable an easy and hitch-free imperialism. It is a common knowledge that economic activities cannot thrive where conflict exists.

The colonial government instituted the 'divide-and-rule' policy in Sudan, which was done mainly for the Sudanese to distrust, fear, and fight each other, instead of their colonizers. This policy separated southern Sudanese provinces from the rest of the country and slowed down their economic and social development. The British authorities, for example, claimed that the south was not ready to open up to the modern world while at the same time, heavily investing in the Arab north, modernizing and liberalizing political and economic institutions and improving social, educational, and health services (Heleta 2008).

The colonial administration also introduced a policy of indirect rule in the southern parts, which largely divided the south into hundreds of informal chiefdoms. This created a serious bifurcation of the region that lasted long after the independence of 1956 and that of 2011. Indirect rule prevented the country's unification, exacerbated tribalism in the north, and served in the south to buttress a less-advanced society against Arab influence (Metz 1991).

Arguably, the post-independence Sudan having about 600 ethnic groups speaking over 400 languages was largely ensnared by the ethnic divisions created by colonialism. Under the British separatist policies, the south became economically underdeveloped and cut out from the rest of the country. Consequent upon this underdevelopment and the lack of political organizations and unity, the southern region was not prepared and empowered to actively participate in the administration of the newly independent country. For exam- 
ple, from 1956 until the secession of the south in 2011, no president from the south emerged. Regional differences resulted in a deeply divided and economically differentiated Sudan - an Arab-dominated north, economically and politically stronger than an underdeveloped and weaker African south. The new indigenous government of Sudan continued with the colonial policy at the detriment of the south. Thus, the southern provinces, sidelined during the British rule, continued to be marginalized and underdeveloped in independent Sudan controlled by the northerners. This consequently triggered the southern rebellion and two civil wars that ravaged the country for the most part of the second half of the twentieth century.

The people of the Republic of South Sudan are factionalised into different ethnic, cultural and religious groups. According to the World Bank report (2013), South Sudan's population consists of more than 200 different ethnic groups (World Bank Development Report 2013). The Dinka, as the biggest group, account for about 36 per cent of the population, while the Nuer, as the second biggest, represent about 16 per cent. Political power is often based on tribalism and ethnic heritage. This can be seen in the composition of the government and the new opposition. President Kiir, an ethnic Dinka, and then vice-president Machar, an ethnic Nuer, formed a power sharing alliance and the government was to represent the most dominant ethnic groups in order to have a broad supporter base and legitimacy (Stolpe 2014).

It has to be noted that while the 1956 independence boosted ethnicity between the north and south, there was a profound fecundity in the south even after the 2011 independence. Thus, secession or independence did not end the problem of ethnicity in the Sudan, especially in the south. Inter-ethnic wrangling in south Sudan in some cases predates the war of independence. In December 2011, for example, tribal clashes in Jonglei were reported between the Nuer White Army of the Lou Nuer and the Murle over cattle dispute. ${ }^{1}$ However, south Sudan's ethnic problem has its origin at the formative stage of the Sudanese People's Liberation Movement and Army (SPLM/A) in which leaders of some of the prominent ethnic groups such as the Neur and Dinka found it difficult to reach a consensus on the formation of a liberation movement for southern Sudan (Arop Madut Arop 2009).

Similarly, intra-faction discords which were rampant following the end of the second civil war in Sudan in 2005 was as much a battle within South Sudan, as it was a battle with the Sudanese government. The two major ethnic groups namely Nuer and Dinka have become notoriously quarrelsome since independence. This led to the schism in the SPLM giving birth to The Sudan People's Liberation Movement-inOpposition (SPLM-IO), also known as anti-governmental forces (AGF) which is mainly Nuer South Sudanese political party and rebel group at the instance of the civil war that occurred shortly after independence. At the centre of this has been the struggle between President Salva Kiir, an ethnic Dinka, and the former Vice President Riek Machar, an ethnic Nuer. The SPLA, the national army formed out of former rebel movements and other militia groups, split into different factions, some supporting their own ideas and the two biggest parts aligning themselves through ethnic affiliations with either the government of President Kiir or with Riek Machar, who heads the SPLM-IO. ${ }^{2}$

Generally, post-independent south Sudan has been bedevilled by ethnic tensions. There is a border dispute with Sudan, the oil rich region of Abyei being the main con- 
tentious issue. The northern regions, mainly in Jonglei state, are plagued by a high intensity conflict with inter-ethnic violence. The Dinka, Murle, Nuer and other ethnic groups and tribes are fighting against each other over different issues, mainly about cattle raids and retaliation attacks. However, the fighting is not only inter- but intra-ethnic as well. Other militias throughout South Sudan continued fighting over political influence or other incentives. While some joined the official military after an amnesty offered by President Kiir, others engaged in violent attacks or claimed control over regions using violent means (Stolpe 2014).

\section{Inequality and African Development}

There exists a symbiotic relationship between inequality and development. Like ethnicity, inequality is a hydra and it is viewed through the lenses of economic or income inequality, political inequality, group inequality, gender inequality, etc. Inequality breeds disparity, which is visibly identified in employment, education, health care services, spatial distribution and political or power distribution with the potential of increasing poverty and also, causing collective political violence, which can constrain growth through multiple effect (Cramer 2003: 398). Inequality is a social-political and economic liability to any society; moreover, it is a global phenomenon, not peculiar to Africa only. Other parts of the world are equally grappling with it. The Occupy Wall Street campaign is no different from the agitations of young people in Tunisia and Egypt or the service delivery protests in South Africa. The difference is that given limited resources and opportunities, Africa's capacity to absorb those shocks and the pain of inequality is limited; hence, it is more visible and produces greater impact on the continent.

The drivers of inequality are complex and multidimensional ethnic (UNDP 2013: 2). Willems (2012) classified inequality into three, namely economic inequalities, which include access to and ownership of financial, human, natural resourcebased and social assets including inequalities in income levels and employment opportunities; social inequalities which include access to services like education, healthcare, housing, etc.; political inequalities which include the distribution of political opportunities and power among groups, such as control over local regional and national institutions of governance, army and police, including people's capabilities to participate politically and express their needs; and cultural inequalities which include disparities in the recognition and standing of language, religion, customs, norms and practices of different groups (Gumede 2013). In spite of the fact that all these in one way or another suffice the explanation of African underdevelopment, economic inequality seems to take the lead in this regard.

A common guage used by scholars in the measurement of inequality, particularly economic inequality has been the Gini Coefficient. Umukoro (2014) reported that Nigeria gets 43.7 (0.437) in 2003 on this scale, making it more unequal than Ghana, Senegal, Tanzania and Egypt to name but a few. This statistics while offering a snapshot of the situation in regards to income, does not tell the whole story. There is also inequality of opportunities which is difficult to measure, it exists in all spheres of life. There is unequal access to education, healthcare, justice, security, capital and even political representation. Some are able to live as full citizens while the majority are offered little by the state and are left to fend for themselves (Chukwueke 2010). Thus, an important 
problem elicited through this methodology is that such statistics fail to look at the political significance of inequalities, which is the major factor that matters more in most cases than the others. The recent research has therefore focused on crosscutting cleavages and horizontal inequalities aimed at gaining insight into which factors contribute to make inequality matter. Horizontal inequalities are multidimensional and inclusive, involving access to a variety of resources along economic, social, and political vectors or dimensions. Thus, inequality transcends the economic dimension; not only income is important, but access to employment and to a variety of assets.

Horizontal inequalities are inequalities between different groups in a country, which can be defined by ethnicity, race, gender or region (Brinkman et al. 2013). Economic inequalities are only part of the picture. Across Africa, health, education, social welfare and many other aspects of human well-being are also marked by wide disparities. In Guinea, for example, 48 per cent of all people visiting hospitals and primary health facilities come from the richest fifth of the population. Those from the poorest fifth make up only 4 per cent of patients (Harsch 2006).

It should be noted, however, that educational inequalities in Africa go beyond gender. It is caused by government insensitivities to policy formulation and implementation. In Nigeria, for example, poor implementation of policies has led to a great decline in education service delivery and to a situation in which private schools are being patronised by only those who can afford quality education. Those who cannot afford it are simply enrolled in poorly equipped government/public schools. Even government officials and wealthy individuals prefer to send their children to schools abroad in Europe or the USA.

With regard to health inequality, while the gap between the poorest and the richest has narrowed particularly with access to health care because of the introduction of the national health insurance scheme (NHIS), maternal mortality among rural women remains higher than among their urban counterparts. There is evidence to suggest that the children from the poorest households are more than twice likely to die before their fifth birthday than those from the richest households. The Multiple Indicator Cluster Survey (2006 and 2011, Ghana) data reveal that this situation appears to be worsening as the gap between the poorest and the richest households has widened considerably over the last two survey periods.

Inequality and politics interact often in negative ways. Inequalities in income and human capabilities often reflect inequalities in political power. Poor people, women, rural population and marginalized ethnic groups are disadvantaged in part, because they usually are badly organized, have a weak political voice and in many countries are excluded from major areas of decision-making - especially those involving the distribution of economic and social resources. Unequal political power leads to the formation of institutions that perpetuate inequalities in power, status and wealth. It is therefore, argued that inequality can constrain growth through political effects. Hence, Alesina and Perotti (1996, cited in Cramer 2003) found out that inequality is correlated with a greater incidence of political instability and it is a statistically proven disincentive to investment. Therefore, again, inequality indirectly reduces the possible rate of growth. At the extreme, of course, this same chain of causality might bring about not isolated political assassinations but full-blown organized violence, for example in the form of a civil war (Cramer 2003: 398). 
Empirical evidence suggests that income inequality, employment inequality, education inequality and political power inequality significantly correlate with development (Alesina and Perotti 1996; Franck and Rainer 2012; Ibor et al. 2015; Kester 2008). Africa is the second-most inequitable region in the world, after Latin America. According to the publication of the African Development Bank in 2012, inequalities have not diminished over time. In 2010, six out of the ten most unequal countries worldwide were in sub-Saharan Africa (The Pain of Inequality in Africa 2014). Education, spatial, gender, employment and income inequalities all coalesce to deny people their basic socioeconomic rights and a stake in the system, which sometimes fuels political conflict. The warped motive of the Boko Haram insurgency in Nigeria may not directly relate to inequality, but its combustive elements do relate. Ignorance and deprivation are two factors that have probably made it possible for the terrorist group to recruit young people to kill and maim their fellow citizens. However, with good education and decent jobs available, it would have been difficult for the dreaded group to recruit members.

According to Lichbach (1989) inequality is the major cause of disagreement. Focusing on the political economy of Sub-Saharan African states, he argues that the major reason of inter-group violence is the unequal access of groups to socio-economic welfare. He argued that a political rule, prevalent across African states, based on combining corruption and ethnic favouritism create incentives for individuals to mobilize collectively and violently against other groups in order to secure access to scarce economic benefits. The larger the difference between the haves and the have-nots, the more competitive these distributional conflicts will be.

Since independence there has been conspicuous inequality in power distribution among the nations of Africa. Since most countries on the continent are divided along ethnic lines with majority and minority configurations, political power has become almost the exclusive right of the majority. This is a problem in many multiethnic African nation states with histories of marginalising certain ethnic groups or entire regions from the distribution of power and resources, but it becomes rather complicated in cases like Somalia, where everyone is Somali, but divided along clan lines (Agbu 2011). Indeed, the practice of democracy in Africa encourages inequality in power distribution. This owes to the fact that democratic arrangement does not go far enough to empower the majority of African people. Rather, it enables the elite (minority) to dominate political and economic power. In this regard, inequality in power distribution and democratisation may depend on two issues: how it is susceptible to manipulation by the dominant elite, and the ways in which identity may become a platform for excluded groups to organize and struggle for group interests.

In many African countries, political power translates directly into economic power, since the private sector is not advanced in much of the continent and because the structure of single-commodity economies makes it easier to concentrate wealth in the hands of a privileged few. The reality is that many African governments have persistently failed to govern in the interest of all their citizens, whose experience is one of persistent lack of genuine democracy, the continued monopoly of politics and money in the hands of small elites, and stagnating - or worsening - living conditions (Gumede 2013). 


\section{Contextual Comparison: Nigeria and South Sudan}

The case studies of this presentation namely Nigeria and South Sudan offers salient examples of how ethnicity coalesces with inequality to spell unmitigated tragedy on the African continent. Both countries belong to some of the highly polarized countries in Africa, which mobilized ethnicity to gain independence. Nigeria and South Sudan are both stratified societies. However, South Sudan is a relatively new country and less populous. Both countries were shaped by assumptions and definitions imposed by the British rulers. British imperial rule in both countries provided identities, languages and symbols for ethnic and racial groups. Colonial racism was responsible for creating ethnic divisions and encouraging regionalism and separatism, which further separated the races and ethnic groups.

Nigeria, a country inhabited by 470 ethnic groups, distinguished by language, customs and religious beliefs, also vary in education and level of employment in the different sectors of economy. With about 120 million people, Nigeria is Africa's most populous country. It is home to 250 linguistic groups, but English is also Nigeria's chosen official language. Although most of the ethnic groups are very tiny, three ethnic groups constitute somewhere between 60 and 70 per cent of the population. The Hausa-Fulani ethnic groups count for 30 per cent of the population, the Yoruba about 20 per cent and the Igbo about 18 per cent. These three major ethnic groups are differentiated not only by region, but also by religion and life-style. It has a North - South divide, but politically divided into six geopolitical zones; three in each of the major divisions. The southern region of the country is traditionally considered to have much higher levels of education and employment in the public sector than groups in the northern region (Ibor et al. 2015). South Sudan on the other hand, a relatively newly independent African countryo is divided along 64 ethnic groups with two ethnic groups standing as the majority of ethnic groups. That is why the governmental administration is shared according to the size of ethnic groups. What this portends is that if government positions were to continue to be allocated based on the percentage proportion of each tribe of South Sudan, then the Taposa ethnic group would receive 4.20 per cent of the national government, the Shilluk - about 2.98 per cent and Ayuak - about 0.80 per cent (PaanLuel Wel 2015) according to their population.

Nigeria as a heterogeneous society has continually faced the problem of ethnic consciousness as it has been entrenched in the Nigeria society to the extent that any activity or programme of action initiated by the government of the day is seen as being influenced by ethnic considerations. This situation is fast becoming a value and consciously taught among each nationality in Nigeria and propagated to capture political positions has caused more harm than good to national integration and harmony (Idowu 2015). Ethnic politics continue to pose a security threat to many African countries and has had adverse effects on prospects of promoting good governance or democracy. By the same token, when President Salva Kiir accused his former vice president, Riek Machar, of plotting a coup, hundreds of civilians died in ensuing attacks reportedly targeting Machar's ethnic group, the Nuer, in Juba in the first days of the conflict; revenge attacks by Nuer against Kiir's ethnic group, the Dinka, followed, and the retaliatory violence spread. These two countries, continue to use ethnicity as a resource for political manipulation and entrepreneurship, resulting in dominant ethnic groups excluding minority 
groups within national policies that reflect the interests and activities of the national majority. As a result, many minority groups in Africa have been denied their democratic rights of equal access to socio-economic, political and cultural resources resulting in a security dilemma. The term security dilemma is commonly used in realist theory of International Relations to refer to a situation where competition for state power and scarce resources leads to a zero-sum conflict (win-lose) of identities based on tribalism or ethnicity.

Differences of educational attainment, occupational level and land holdings across ethnic groups lead to a security dilemma, which causes separatist or ethnic conflict. South Sudan produces the ethnic security dilemma where ethnic grievances prevailed due to unequal or unfair governance resulting in inter-communal violence between the Murle and Nuer tribes in Jonglei. The conflict led to the Murle demanding an independent state of their own, from Jonglei, due to lack of representation in the state government. The dissatisfaction with the political processes and state government created an environment of uncertainty that has made it relatively easy to mobilize people for the use of violence (Butale 2015).

The civil wars in these two countries (Nigeria 1967-1970 and South Sudan since 2011) almost immediately after independence were fought along ethnic lines. While the war remains unabated in South Sudan, the seeds of the Nigerian civil war still hover around the polity. Arguably, unequal political power distribution is a major cause of disagreement in Africa in general. Accordingly, political parties in Nigeria employ an informal zoning formula in which case they rotate the presidential candidacy between the North and South and other elective offices among the ethnic groups. There has been a president of Yoruba origin in Nigeria. The Igbo has produced a Vice President and on more than one occasion has produced the Senate President, the most senior national legislator and the third highest national office in Nigeria. The immediate past President of Nigeria is from the South-South region of Nigeria. The Yoruba, Igbo, and the groups in the South-South have all produced high-ranking members of the national judiciary (Okojie 2013: 446).

The politics of domination the Dinka elite pursue in South Sudan for the control of economic and political power is the main source of incessant conflicts among ethnic groups in the country. In other African countries, the proportion in which ethnic groups that produce the national wealth have access to political power or excluded from it may account for ethnic conflicts in the nation. For instance, the entire budget of Unity State in South Sudan, including two per cent oil share of the state, is a property of the Governor. Sometimes civil servants take one year without receiving their salaries because the political leaders both at the state and national levels divert the money to their private accounts (Buay 2012). Experience in Nigeria, which is a worst case scenario has revealed that national interest has been shoved aside as politicians use public money to build and maintain patronage networks. Since independence, the situation in Nigeria has been fraught with ethnic politics whereby the elite from different ethnic groups schemed to attract as many federal resources to their regions as possible, neglecting the issues that could unite the country (Irobi 2005).

After independence, the regions in Nigeria embarked on a policy that based employment into the regional civil service along ethnic lines, thus making it difficult for 
a qualified but non-indigene residing in any of these regions to be employed in the regional civil service. In his study carried out to understand the situation in southwestern Nigeria, Kester (2008) revealed that ethnic affiliation does significantly influence the ethnic domination and inequality in Nigeria's pluralistic organizations. The study shows that about 28 per cent of the minority ethnic groups (such as Ebira, Idoma, Ishan, Tiv, and Ibibi) believed that ethnicity provides avenues whereby the interests of the 'stronger' ethnic groups pre-empt and dominate organizational policy/policies and even public policies. Thus, this raises a constant fear among the minority groups who fear of being subjugated or relegated to the background within the polity. In such instance, holding a high position in the civil service is holding it in trust for the benefit of their ethnic nationality alone. Similarly, the decision-making process is heavily dependent on the persons and groups, which claim the loyalty of the person in authority (Kester 2008: 227-228). Putting it succinctly, Mustapha (2003) observes that what we have in Nigeria today is what can be referred to as ethno-nationalism where civil servants or bureaucrats have certain region(s) as their stronghold and through this engage themselves in a struggle for power and privileges with other ethnic groups. Ethnic identities, therefore often remain the major point of departure and serve as a major obstacle to patriotism.

The institutionalization of ethnicity as a powerful tool for access to public resources and political power has indeed corrupted the state and society in South Sudan. Ethnicity and loyalty has become more valuable than merit and qualification. For instance, securing a job can be difficult if the person belongs to the wrong ethnic group. The popular perception among many South Sudanese is that hiring decisions and promotion prospects are linked to a person's ethnic identity. Such perceptions of ethnic group favouritism are even more common when it comes to resources controlled by the government. In Nigeria, since resources - grants, jobs, scholarships, social infrastructure, public investments etc. - are shared on the basis of territorially defined states and local governments, the ethnic majority groups who control the preponderant numbers of these units continue to enjoy a preponderant share, and this is coming on top of their already accumulated advantages (Mustapha 2003). Even in states where non-indigenes find themselves, there is a natural division into citizens and strangers in which only true indigenes determined by blood ties and ethnicity, not just anybody living there, no matter how long they may have been resident there, can have access to resources allocated to the state or local government in question.

Both countries represent Africa where ethnicity and inequality have joined forces to breed poverty. A veneer exists in which some of the richest men in the world are domiciled in Africa. Nigeria, for example, produces some of the richest men in Africa, yet the country is one of the poorest countries of the world. According to the Global Finance Magazine, Nigeria ranks 140, out of 184 countries with a GDP per capita of US\$ $2,883.44$ and unsurprisingly, African countries make up most of the poorest countries in the world, with the Congo falling to the bottom of the list at just US\$ 394.25 per person in the country. Unequal growth concentrates wealth in the hands of several individuals who mostly gain economic advantage as a result of the privileged political position they occupy. 


\section{Conclusions}

Thus far, this paper has reinforced the increasingly popular argument that ethnic heterogeneity is causally related to inequality in Africa. Again, while the argument is contentious it does fit the facts of Africa as represented by Nigeria and South Sudan as a continent whose development is increasingly encumbered by ethnicity and inequality.

Most often ethnic sentiments are used to replace merit and skills, such that round pegs are no longer found in round holes. This chauvinistic behaviour affects the efficiency and productivity of states and has continually retarded development. Similarly, recruitment, selection and placement in public sector establishments in these countries are done based on ethnic considerations, which take pre-eminence over meritocracy with the attendant consequences on administrative efficiency.

Political independence of these countries under study has uncovered buried ethnic sentiments among federating elements. The long decades of the national liberation struggle prevented South Sudan from looking into its soul to discover its own societal ills. The task of self-reflection and criticism had not been accomplished prior to the declaration of political independence. Instead of moving away from the illusion of tribalism and ethnicity, the political elites reshaped the basis of government. Ethnicity, which encouraged majority - minority dichotomy has also created a situation in which many minority groups in Africa have been denied their basic rights of equal access to socioeconomic, political and cultural resources resulting in a security dilemma. Differences of educational attainment, occupational level and land holdings across ethnic groups lead to a security dilemma which causes separatist or ethnic conflict. Generally, this paper concludes that both variables namely ethnicity and inequality have generated unmitigated tragedy that has continually stunt the overall development of Africa.

\section{NOTES}

${ }^{1}$ URL: http://www.aljazeera.com/news/africa/2012/01/201212101840599359.html.

${ }^{2}$ URL: https://www.insightonconflict.org/conflicts/south-sudan/conflict-profile/South Sudan: Conflict profile.

\section{REFERENCES}

A Brief History of Modern Sudan and South Sudan. URL: http://www.waterforsouth sudan.org/brief-history-of-south-sudan/

Adebayo Oyebade. 2002. Reluctant Democracy: The State, the Opposition, and the Crisis of Political Transition, 1985-1993. In Adebayo Oyebade (ed.), The Transformation of Nigeria: Essays in Honor of Toyin Falola (pp. 137-165). New Jersey: Africa World Press.

Adebisi, M. A. 1998. Ethnic Relations in Nigeria. In Igum, U. A., and Mordi, A. (eds.), Contemporary Social Problems in Nigeria Shebiotimo Publications. Lagos: Sebiotimo Publication.

Agbu, O. A. 2011. Ethnicity and Democratisation in Africa Challenges for Politics and Development. Discussion Paper 62: 8-11). Uppsala: Nordiska Arikainstitutet.

Alesina, A., Michalopoulos, S., and Papaioannou, E. 2016. Ethnic Inequality. Journal of Political Economy 124 (2): 428-488.

Alesina, A., and Perotti, R. 1996. Income Distribution, Political Instability, and Investment. European Economic Review 40 (6): 1203-1228. 
Archer, S. 2009. Why do Kenyans Vote along Ethnic Lines? A Study of Underlying Rationales for Kenyan Electoral Behaviour. Master Thesis. Department of Political Science, University of Oslo. URL: https:/www.duo.uio.no/handle/10852/15069.

Arop Madut Arop 2009. The Founding of the People's Revolution: SPLM/SPLA (19832005). The New Sudan Vision, May 16. URL: http://www.newsudanvision.com/ sudan/1694-the-founding-of-the-peoples-revolution-splmspla-1983-2005.

Asafa J. 2015. The Tripple Causes of African Underdevelopment: Colonial Capitalism, State Terrorism and Racism. International Journal of Sociology and Anthropology 7 (3): 75-91.

Blake, M. 2013. Worlds Apart: Uganda Tops List of Most Ethnically Diverse countries on Earth while South Korea Comes Bottom. Daily Mail, May 17. URL: http://www. dailymail.co.uk/news/article-2326136/Worlds-apart-Uganda-tops-list-ethnically-diversecountries-Earth-South-Korea-comes-bottom.html

Brinkman, H.-J. et al. 2013. Addressing Horizontal Inequalities as Drivers of Conflict in the Post-2015 Development Agenda Addressing Inequalities. United Nations Peacebuilding Support Office. URL: http:/www.saferworld.org.uk/downloads/Inequalities-conflictFV.pdf.

Buay, G. 2012. The Colour of Ethnic Domination in South Sudan. Sudan Tribune. March 19. URL: www.sudantribune.com/spip.php?article41947.

Butale, C. 2015. Ethnic Politics as a Cause of Ethnic Inequalities in Africa. https://iapss. org/2015/11/29/ethnic-politics-as-a-cause-of-ethnic-inequalities-in-africa/

Chukwueke, Enyinnaya E. 2010. Inequality in Nigeria. A Look at Nigeria as We Approach the 2011 Elections. URL: http://2011 openletter.blogspot.com.ng/2010/10/inequality-innigeria.html

Copnall, J. 2014. A Poisonous Thorn in Our Hearts: Sudan and South Sudan's Bitter and Incomplete Divorce. London: C. Hurts \& Co. (Publishers) Ltd.

Cramer, C. 2003. Does Inequality Cause Conflict? Journal of International Development 15 (4): 397-412. Wiley InterScience. URL: www.interscience.wiley.com

de Chand, D. 1995. South Sudan Claims for Right of Self-Determination. University of Pennsylvania. URL: http://www.africa.upenn.edu/Articles_Gen/de_chand.html

Deng, F. M. 1997. Ethnicity: An African Predicament. 1 June. Brookings. URL: https://www.brookings.edu/articles/ethnicity-an-african-predicament/

Dickson, A. A., and Dadiowei, T. E. 2010. Impact Mitigation Monitoring as an Environmental Conflict Management Tool: The Gbaran- Ubie Integrated Oil and Gas Project Experience. In Albert, O. I., and Oloyede, I. O. (eds.), Dynamics of Peace Processes (pp. 465-486). Ibadan: John Arhers Publishers Ltd.

Easterly, W., and Levine, R. 1997. Africa's Growth Tragedy: Policies and Ethnic Divisions. Quarterly Journal of Economics 112: 1203-1250.

Ekokobe S. Awung 2011. A Critical Analysis on the Reasons of Underdevelopment in Africa. Munich: GRIN Verlag. URL: http://www.grin.com/en/e-book/168420/a-criticalanalysis-on-the-reasons-of-underdevelopment-in-africa p. 2.

Ethnic Groups in the Democratic Republic of the Congo (Congo-Kinshasa). 2018. URL: http://www.worldatlas.com/articles/ethnic-groups-in-the-democratic-republic-of-thecongo-congo-kinshasa.html. 
Franck, R., and Rainer, I. 2012. Does the Leader's Ethnicity Matter? Ethnic Favouritism, Education and Health in Sub-Saharan Africa. American Political Science Review 106 (2): 294-325.

Gumede, W. 2013. Power and Inequality in Africa. https://democracyworks.org.za/powerand-inequality-in-africa/.

Harsch, E. 2006. Combating Inequality in Africa. URL: http://www.un.org/africa renewal/magazine/july-2006/combating-inequality-africa.

Heleta, S. 2008. Roots of Sudanese Conflict are in the British Colonial Policies. Sudan Tribune. January 13. URL: http://www.sudantribune.com/Roots-of-Sudanese-conflictare-in, 25558.

Human Development Report. 2015. Work for Human Development UNDP (pp. 210-211). New York.

Ibor, U. W., Egolıkuma, F., Isa, D. 2015. Spatial Analysis of Employment Distribution in the Federal Civil Service, Nigeria. Journal of Educational and Social Research MCSER Publishing 5 (1): 265-276.

Idowu, A. S. 2015. Functional Ethnicity, Regionalism and Regional Integration of South West Nigeria: A Study of Odu'a Investment Company Limited (OICL). Global Journal of Human-Social Science: E Economics 15 (8).

Igbuzor, O. Constitution Making and the Struggle for Resource Control in Nigeria. URL: https://www.dawodu.com/igbuzor1.htm. Accessed December 2, 2016.

Irobi, E. G. 2005. Ethnic Conflict Management in Africa: A Comparative Case Study of Nigeria and South Africa. Accessed June 24, 2019. https://www.beyondintractability.org/ casestudy/irobi-ethnic.

Kester, K. O. 2008. Ethnic Factors as Correlates of Employees' Performance in Selected Federal Bureaucracies in Ibadan Metropolis, Oyo State, Nigeria. Journal of Social Science 16 (3): 227-234.

Largest Ethnic Groups in Uganda. 2018. URL: http://www.worldatlas.com/articles/largestethnic-groups-in-uganda.html.

Lichbach, M. I. 1989. An Evaluation of 'Does Economic Inequality Breed Political Conflict' Studies. World Politics 41 (4): 431-470.

Metz, H. C. (ed.) 1991. The Anglo-Egyptian Condominium, 1899-1955. In Metz, H. C. (ed.), Sudan: A Country Study. Washington: GPO for the Library of Congress. URL: http://countrystudies.us/sudan/15.htm.

Mozaffar, S. 2006. Party, Ethnicity and Democratisation in Africa. In Katz, S. R., and Crofty, W. (eds.), Handbook of Party Politics London: Sage Publications.

Mustapha, A. R. 2003. Ethnic Minority Groups in Nigeria - Current Situation and Major Problems. Comission on Human Rights. Working Group on Minority, Ninth Session, Queen Elizabeth House. May 12-16. University of Oxford.

Nnoli, O. 1980. Ethnic Politics in Nigeria. Enugu: Fourth Dimension Publishers.

Okojie, O. S. 2013. Between Secession and Federalism: The Independence of South Sudan and the Need for a Reconsidered Nigeria. Global Business \& Development Law Journal 26 (2): 415-474.

Olaosebikan, A. J. 2010. Conflicts in Africa: Meaning, Causes, Impact and Solution. African Research Review 4 (4): 549-560.

Osaghae, E. E. 1991. Ethnic Minorities and Federalism in Nigeria. African Affairs 90: 237-58. 
Osaghae, E. E. 1992. Managing Ethnic Conflicts under Democratic Transition in Africa: The Promise and the Failure. In Canon, B. et al. (eds.), Proceedings of the Symposium on Democratic Transition in Africa. Ibadan. June 16-19.

PaanLuel Wel. 2015. Power-Mapping of Ethnicity in the Republic of Sudan. Bringing South Sudanese Together. February 16. URL: http://www.gurtong.net/ECM/Editorial/ tabid/124/ctl/ArticleView/mid/519/articleId/16193/Power-Mapping-of-Ethnicity-in-theRepublic-South-Sudan.aspx.

Paglia, P. 2007. Ethnicity and Tribalism: Are These the Root Causes of the Sudanese Civil Conflicts? African Conflicts and the Role of Ethnicity: A Case Study of Sudan. Africa Economic Analysis.

Rupesinghe, K., and Tishkov, V. 1996. Ethnicity and Power in the Contemporary World. New York: United Nations University Press.

Salawu, B., and Hassan, O. A. 2011. Ethnic Politics and its Implications for the Survival of Democracy in Nigeria. Journal of Public Administration and Policy Research 3 (2): $28-33$.

Skutsch, C. 2006. Ethnic Conflicts in Central Africa. In Leonard Thomas, M. (ed.), Encyclopaedia of the Developing World (pp. 589-590). New York - London: Taylor and Francis Group.

South Sudan Country Profile. URL: http://www.bbc.com/news/world-africa-14069082.

Stolpe, F. 2014. Beyond Greed and Grievance in South Sudan-Analysis of Ethnically and Politically Motivated Violence. Bachelor Thesis. Westfälischer Wilhelms-Universität. Münster. URL: www.uni-muenster.de/imperia/md/content/ifpol/sic/.../bachelorthesis stolpe.pdf

Suberu, R. 1996. Ethnic Minority Conflicts and Governance in Nigeria. Ibadan, Owerri: Spectrum Books Limited.

The Pain of Inequality in Africa. 2014. New African Accessed June 242019 http://newafricanmagazine.com/pain-inequality-africa/\#sthash.5NsjYqFY.dpuf.

Tongun Lo Loyuong 2014. Why are the Dinka and Nuer Killing Each Other in South Sudan? URL: https://tloloyuong.wordpress.com/2014/01/23/explaining-current-internalarmed-conflict-in-south-sudan-to-german-audience-from-an-ethnic-lens/.

Umezinwa, C. 2012. Ethnicity and Nigeria's Underdevelopment. Ogirisi: A New Journal of African Studies 9: 215-229.

Umukoro, N. 2014. Democracy and Inequality in Nigeria. Journal of Developing Societies 30(1): 1-24.

UNDP. 2013. Humanity Divided: Confronting Inequality in Developing Countries. URL: www.undp.org/poverty.

Willems, R. 2012. When Do Inequalities Cause Conflict? Focus on Citizenship and Property Rights. The Broker. URL: http://www.thebrokeronline.eu/Articles/When-do-inequalitiescause-conflict

Warburton, C. E. S. 2005. The Evolution of Crises and Underdevelopment in Africa. Lanham, MD: University Press of America.

World Bank Development Report. 2013. World Bank Development Report. Washington, DC: World Bank.

Yang, P. Q. 2000. Ethnic Studies: Issues and Approaches. Albany: State University of New York Press. 